\title{
Dynamic analysis of a concrete chimney considering the aerodynamic damping
}

\section{Análise dinâmica de uma chaminé de concreto considerando o amortecimento aerodinâmico}
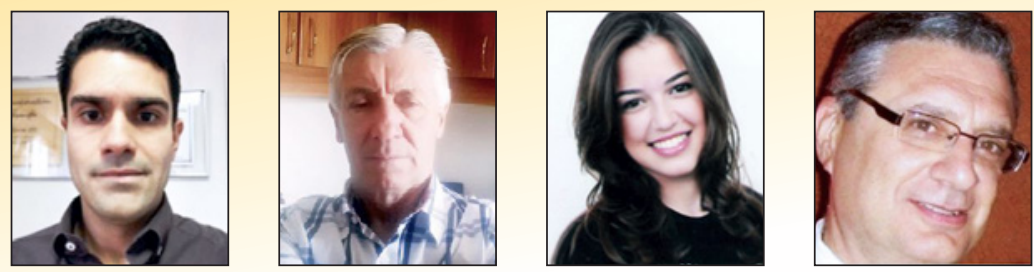

\author{
H. CARVALHO \\ hermes@dees.ufmg.br \\ https://orcid.org/0000-0002-4652-8068 \\ G. QUEIROZ a \\ gilsonmaque@gmail.com \\ https://orcid.org/0000-0001-5341-8054
}

P. M. L. VILELA a paulinhamlvilela@gmail.com https://orcid.org/0000-0002-7442-0601

R. H. FAKURY a

fakury@dees.ufmg.br https://orcid.org/0000-0002-1884-5699

\begin{abstract}
Usually, the analysis of structures under wind loading is performed using an equivalent static analysis, where the influence of floating response is taken into account by the gust factor. This methodology can be used in case of rigid structures for not presenting a considerable dynamic response. More flexible structures, in particular those lightly damped, may show an important resonant response and their dynamic properties must be considered in the analysis. The aim of this paper is to present a methodology for dynamic analysis of structures under wind loading considering the geometric nonlinearity, the vibration caused by the kinetic energy of wind gusts and the aerodynamic damping due to the relative movement between this structure and the wind. The formulation proposed is applied to a 180-meter-high concrete chimney and the results were compared with those obtained through the recommendation given in the standard ABNT NBR 6123:1988 [2] for the dynamic structural analysis.
\end{abstract}

Keywords: structures subjected to wind loads, nonlinear dynamic analysis, fluid-structure interaction, aerodynamic damping.

\section{Resumo}

Tradicionalmente, estruturas submetidas ao vento são avaliadas através de análises estáticas com carregamentos equivalentes, onde a influência da resposta flutuante é levada em conta por meio do fator de rajada. Essa metodologia é aplicável a estruturas suficientemente rígidas para não apresentarem resposta dinâmica ponderável [ ]. Estruturas mais flexíveis, em particular aquelas fracamente amortecidas, podem apresentar importante resposta ressonante e devem ter suas propriedades dinâmicas consideradas na análise. O objetivo deste artigo é apresentar uma metodologia para a análise dinâmica de estruturas submetidas ao vento considerando a não-linearidade geométrica, a vibração causada pela energia cinética das rajadas de vento e o amortecimento aerodinâmico devido ao movimento relativo entre a estrutura e o vento. A metodologia proposta é aplicada à estrutura de uma chaminé de concreto com 180 metros de altura, sendo os resultados comparados com os obtidos através das recomendações da norma ABNT NBR 6123:1988 [ ] para a análise dinâmica de estruturas.

Palavras-chave: estruturas sujeitas ao vento, análise dinâmica não-linear, interação fluido-estrutura, amortecimento aerodinâmico. 


\section{Introduction}

Accidents with structures subjected to wind which did not reach the design speed indicate that the collapse may have been caused by dynamic effects or errors in the estimation of wind force. When is it necessary to consider the dynamic effects of the wind? Naturally, it is not possible to provide a simple answer to the problem. One way to solve this question is to calculate the efforts due to the wind, with or without taking into consideration the dynamic effects, in order to verify the difference between the answers. Once a tolerable difference is indicated, the engineer can set the calculation methodology that will be employed on each structural typology.

The proposed question aims to verify whether a structure can be considered rigid (negligible dynamic effects) or flexible (dynamic effects should not be neglected). (Hirsch and Bachmann [3]) suggest that a structure subjected to wind is defined as rigid if the dynamic response to gust or turbulence effects does not exceed up to $10 \%$ of the static response. Structural systems subjected to wind forces present themselves in different forms, for example: cables, low and high buildings, chimneys, towers, bridges, among others. Thus, it is a complex task defining parameters for the evaluation of the necessity to perform dynamic analyses in the design of the most varied types of structures.

Several researchers have developed studies involving dynamic analyses in different typologies of structures. For example, (Caracoglia et al. [4]) and (Bobby et al. [5]) evaluated slender buildings, (Ambrosini et al. [6]), (Belloli et al. [7]) and (John et al. [8]) evaluated chimneys, (Tamura et al. [9]), (Henriques et al. [10]) and (Koss et al. [11]) evaluated towers and masts, (Ke et al. [12]) evaluated cooling towers and (Yang et. al [13]) studied the behavior of transmission towers subjected to wind. (Franco [14]) developed a procedure the "synthetic wind" method for the calculation of gust factor, acting in the position of the gust center of the structure, position obtained deterministically.

Assuming that the mean velocity of the wind remains constant over a representative time interval, the effects on the structure are purely static (mean response). Speed fluctuations can produce, in flexible structures, important oscillations towards the mean velocity (resonant response).

In the design practice, structures submitted to wind are evaluated through static analyses with equivalent loads, where the influence of the resonant response is taken into account by the gust response factor, proposed by Davenport [15]. This methodology is relevant in structures with natural frequencies higher than 2.0 hertz, sufficiently rigid for not presenting significant resonant response [1]. Structures with frequencies lower than this value, mainly weakly damped, may present an important resonant response and must have their dynamic properties considered in the structural analysis. The Brazilian standard ABNT NBR 6123:1988 [2] considers the gust factor method and two models for dynamic analysis for buildings and chimneys with a natural period equal or greater than 1 second. The first, called simplified continuous model is applied to buildings with constant section and uniform mass distribution; the second, discrete model to applied in buildings with variable properties. For the dynamic evaluation of other structural typologies there are no procedures or guidelines in this standard.
This paper aims to present a methodology for the evaluation of the dynamic effects caused by the kinetic energy of wind gusts (atmospheric turbulence), considering the fluid-structure interaction and the geometric nonlinearity. When evaluating the vibrations caused by the wind it is extremely important to consider aerodynamic damping, especially for structures that develop high velocities when excited by wind [16] [17] or present a considerable change in their shape or orientation during the action of external forces.

The proposed methodology limits itself to the influence of aerodynamic damping due to the relative movement between structure and wind, both acting in the same direction. Vibrations caused by von Kármán vortices, galloping, hammering or draping are not considered.

The wind load is determined using statistical methods and the velocity fluctuations are represented by a random stationary and ergodic process. As the proposed procedure is based on instantaneous calculation speeds, the analysis should be performed in the time domain, allowing the calculation of the dynamic forces of the wind at time increment.

\section{Methodology}

In order to evaluate the vibration caused by the kinetic energy of wind gusts in structures, a numerical procedure was developed for dynamic analysis with variable wind forces in time and space. Usual structural damping for concrete structures was taken into account. Aerodynamic damping was considered directly in the determination of the wind dynamic pressures, through the use of relative velocities between the structure and the wind. Geometric non-linearity also was evaluated in the dynamic behavior of the structure.

Wind speed can be expressed as a time function composed of a mean and a floating component. In the proposed procedure, the mean value is obtained from the ABNT NBR 6123:1988 [2] isopleths and the floating velocity is determined by statistical parameters such as probability distribution, power spectrum and crosscorrelation functions.

The proposed procedure is applied to structure of 180-meter-high concrete chimney and the results are compared with the example for the dynamic analysis with the discrete model presented by ABNT NBR 6123:1988 [2]. Finally, in order to highlight some characteristics of the behavior of high concrete chimneys subjected to wind, a more flexible hypothetical chimney was evaluated.

\section{Numerical procedures for dynamic analysis}

\subsection{General description}

The dynamic analysis involves the next stages [17]:

- First Stage: Gravitational forces are gradually implemented. The final configuration of the cable is obtained from a non-linear static analysis (dynamic effects are disabled at this structural loading stage).

- Second Stage: The aerodynamic forces, which correspond to the average portion of the wind speed, are implemented in the 
cable as nodal forces. At this stage, the analysis is already dynamic which implies some additional observations. The loads must be slowly introduced, in small increments, in a way that the cable speed, at this stage, is not expressive, and, therefore, does not interfere in the results of the next stage.

- Third Stage: Wind forces, composed by average and random component, are included, as an arbitrary function of time, for every cable node. The dynamic analysis is processed in a transient regime.

The procedure in question was developed in the commercial program ANSYS ${ }^{\circledR}$ [18], in the ANSYS Parametric Design Language (APDL).

\subsection{Aerodynamic damping}

The formulation for aerodynamic damping as proposed in the study is directly considered in the wind pressure calculation, with the use of relative speed between wind and structure, both in the same direction. The basic formulation for wind pressure and relative speed calculus is presented in the next equations.

$\mathrm{q}_{\text {wind }}=\frac{1}{2} \rho \mathrm{V}_{\mathrm{R}}^{2}=0,613 \mathrm{~V}_{\mathrm{R}}^{2}$

$\mathrm{V}_{\mathrm{R}}=\left(\mathrm{V}(\mathrm{t})-\mathrm{V}_{\mathrm{str}}\right)$

$\mathrm{V}(\mathrm{t})=\overline{\mathrm{V}}(\mathrm{z})+\mathrm{v}(\mathrm{t})$

$\overline{\mathrm{V}}(\mathrm{z})=\overline{\mathrm{V}}_{10}(\mathrm{z} / 10)^{\mathrm{p}}$

where:

$\mathrm{q}_{\text {wind }}$ is wind dynamic pressure;

$\rho$ is the specific mass of the air under normal conditions of pressure $(101320 \mathrm{~Pa})$ and temperature $\left(15^{\circ} \mathrm{C}\right)$;

$V_{R}$ is relative speed between wind and structure, in the node considered;

$\mathrm{V}(\mathrm{t})$ is wind speed;

$V_{\text {estr }}$ is structure speed, in wind direction, in the considered node;

$\mathrm{v}(\mathrm{t})$ is fluctuant component of speed;

$\overline{\mathrm{V}}(\mathrm{z})$ is average longitudinal speed component, calculated in 10 minutes:

$\overline{\mathrm{V}}_{10}$ is project average speed at 10 meters from the ground, calculated in 10 minutes;

$z$ is a height from the ground, in meters;

$p$ is exponential ground rugosity coefficient.

Equation 3.1 presents the classical formulation for the dynamic wind pressure calculation, present in ABNT NBR 6123: 1988 [2], with the modification of the reference speed adopted. In the classical version, wind speed is adopted while in the procedure proposed here the relative velocity between wind and structure is used. In most cases, the structure velocity developed when excited by wind is low or zero, which does not change the dynamic pressure values. However, for flexible structures, velocities can be significant and may have a considerable impact on dynamic pressure values.

It is important to note that the proposed formulation for aerodynamic damping is valid for cases where the movement of the structure occurs in the same direction as the wind speed, with forces resulting in this direction. Thus, Equation 3.2 represents the vector sum of the longitudinal velocity of the wind and the structure velocity in the wind direction. The dynamic wind pressure (Eq. 3.1) is the product of a scalar by relative velocity, therefore has the same direction as the relative velocity vector (longitudinal wind direction). Equation 3.3 presents the decomposition of the wind velocity in a mean and floating part, present in the ABNT NBR 6123:1988 [2] code. The average wind speed plot is a function of height relative to the ground and can be correlated with any average velocity at another height $z$ by the power law, shown in Equation 3.4. According to Blessmann [19], the formulation presented for the power law shows good agreement with experimental data and is based on the change of the amount of motion in a turbulent atmospheric boundary layer. In practice, one of the heights is set to a standard value (speed 10-meter-high, with an average of 10 minutes), and speeds are determined at heights $z$. The exponential coefficient is a function of terrain roughness and the wind speed integration interval, exposed for different land categories and integration time intervals in the ABNT NBR 6123:1988 [2] code.

In dynamic analyses the average velocity with time integration interval equal to 10 minutes [2] must be used, as a described in the following equation:

$\overline{\mathrm{V}}_{10}=0,69 \mathrm{~V}_{0} \mathrm{~S}_{1} \mathrm{~S}_{3}$

where:

$\mathrm{V}_{0}$ is wind gust speed, calculated in a 3-second interval;

$\mathrm{S}_{1}$ is topographic factor according to the ABNT NBR 6123:1988 [2];

$\mathrm{S}_{3}$ is statistical factor associated to the destruction probability, according to the ABNT NBR 6123:1988 [2].

Some studies, among others (Nagao et al. [20]), assessed the spatial correlation between aerodynamic pressures and revealed that the correlations for the "longitudinal speed fluctuation" did not coincide with the "aerodynamic pressure fluctuation" process. However, in this study, it is assumed that the pressures, which act on the structure, are direct functions of the speed, as in the classic model from Davenport adopted in the ABNT NBR 6123:1988 [2], spectral density and crossing correlation functions are not considered for the pressure fluctuation.

Since the values of forces due to wind depend on the velocities assumed by the structure, the vector force is updated for each increment of time and the new values being function of the relative velocity calculated in the previous increment. The programming of this routine was developed using the *vget command, available in APDL language and it was not necessary to interrupt and restart the simulation at each increment of time for an update of the forces.

\subsection{Simulation, in time, of the fluctuant component of wind speed}

For the accomplishment of a nondeterministic dynamic analysis in time domain, the creation of time functions for the floating portion of the longitudinal wind speed is necessary. To create an aleatory sign with a null average, from a given energy spectrum, a Fourier series is used. The function can be generated from the following equation [21]:

$v(t)=\sqrt{2} \sum_{i=1}^{N} \sqrt{S^{V}\left(f_{i}\right) \Delta f} \cos \left(2 \pi f_{i} t+\theta_{i}\right)$ 
where:

$S^{v}\left(f_{i}\right)$ is spectral density function;;

$\mathrm{N}$ is the number of frequency intervals $\Delta \mathrm{f}$ considered in the;

$f_{i}$ is frequency $i$, in Hertz;

$\mathrm{t} t$ is time, in seconds;

$\Delta \mathrm{f}$ is frequency increment, in Hertz;

$\theta_{i}$ is aleatory lag angle, between 0 e $2 \pi$.

When developing the spectrum division, natural frequencies of the structure must be included in the frequencies so that the result is not an underestimate of the real one. The current model is extremely expensive, in computational means, once that for each time interval, a new spectrum division is considered and a summation of the last equation is done.

\subsection{Power spectrum of the turbulence longitudinal component}

The main application of the power spectrum is to determine composition, in frequency, of an aleatory process. For the determination of the spectral density function (PSDF- "Power spectral density functions"), a formulation proposed by Kaimal is used, shown in the following equation [1]:

$\frac{\mathrm{f} \mathrm{S}^{\mathrm{V}}(\mathrm{z}, \mathrm{f})}{\mathrm{u}_{*}^{2}}=\frac{200 \mathrm{x}}{(1+50 \mathrm{x})^{5 / 3}} ; \mathrm{x}(\mathrm{z}, \mathrm{f})=\frac{\mathrm{z} \mathrm{f}}{\overline{\mathrm{V}}_{\mathrm{z}}}$

where:

$f$ is frequency, in Hertz;

$\mathrm{u}_{*}$ is friction speed, in $\mathrm{m} / \mathrm{s}$;

$z$ is height above ground, in meters.

Friction speed can be described as:

$\mathrm{u}_{*}=\frac{\mathrm{k} \overline{\mathrm{V}}_{\mathrm{z}}}{\ln \left(\mathrm{z} / \mathrm{z}_{0}\right)}$

where:

$\mathrm{k}$ is Kárman's constant, approximately 0,4 ;

$\mathrm{z}_{0}$ is terrain rugosity.

\subsection{Statistic characteristics of the interdependence between aleatory processes}

For large structures, not only temporal series but also multiple series correlated in space, are necessary.

The probabilistic distribution of wind speed is considered a normal or Gaussian distribution [22]. Taking e , two aleatory processes, representing wind speed fluctuation at two points of a structure, it is possible to measure their interdependence using the crossspectral density and cross-correlation functions, presented in the next equations:

$S^{\mathrm{v}_{1}, \mathrm{v}_{2}}(\mathrm{f})=\int_{-\infty}^{+\infty} \mathrm{C}^{\mathrm{v}_{1}, \mathrm{v}_{2}}(\tau) \mathrm{e}^{-\mathrm{i} 2 \pi \mathrm{f} \tau} \mathrm{d} \tau$

$C^{\mathrm{V}_{1}, \mathrm{v}_{2}}(\tau)=\int_{-\infty}^{+\infty} S^{\mathrm{V}}(\mathrm{f}) \mathrm{e}^{-\mathrm{F}} \mathrm{e}^{\mathrm{i} 2 \pi \mathrm{f \tau}} \mathrm{df}$

where:

$\mathrm{S}^{v_{1}, v_{2}}(\mathrm{f})$ is the cross spectral density function for points 1 and 2 ;

$\mathrm{C}^{\mathrm{v}_{1}, \mathrm{v}_{2}}(\tau)$ is the cross-correlation for points 1 and 2 ;

$\tau$ is the arbitrary time interval.
Function is expressed by:

$F=\frac{f\left[C_{1 x}^{2}\left(x_{1}-x_{2}\right)+C_{1 z}^{2}\left(z_{1}-z_{2}\right)\right]^{1 / 2}}{\bar{V}(10)}$

where:

$\mathrm{x}_{1}, \mathrm{x}_{2}, \mathrm{z}_{1}$ and $\mathrm{z}_{2}$ are horizontal and vertical coordinates from points 1 and 2 ;

$\mathrm{C}_{1 \mathrm{x}}$ and $\mathrm{C}_{1 \mathrm{z}}$ are decay coefficients in the vertical and transversal directions.

Wind tunnel testing indicates that the values of the decay coefficients depend on several factors, among them, average speed, roughness of the terrain and height above surface. Values of $C_{1 \mathrm{x}}=16$ and $\mathrm{C}_{1 \mathrm{z}}=10$ are suggested for the usual practice in projects [23].

Adopting two temporal series $\left(\mathrm{v}_{1}(\mathrm{t})\right.$ and $\left.\mathrm{v}_{2}(\mathrm{t})\right)$, simultaneously, at points 1 and 2 , means that seja $\tau=0$, a cross-correlation function $\mathrm{C}_{1}$ is obtained.

$\mathrm{C}_{1}=\mathrm{C}^{\mathrm{V}_{1}, \mathrm{v}_{2}}(0)=\int_{-\infty}^{+\infty} \mathrm{S}^{\mathrm{V}}(\mathrm{f}) \mathrm{e}^{-\mathrm{F}} \mathrm{df}$

Calculating the value of $C_{1}$ for different performance ranges $\left(\Delta \mathrm{L}=\left(\mathrm{x}_{1}-\mathrm{x}_{2}\right)\right.$ or $\left.\left(\mathrm{z}_{1}-\mathrm{z}_{2}\right)\right)$, it is possible to build a graphic that correlates the coefficients $\left(C_{1}\right)$ obtained with the performance ranges $(\Delta \mathrm{L})$.

The autocorrelation function of processes (at the same point) is given by:

$C^{\mathrm{V}}(\tau)=\int_{-\infty}^{+\infty} S^{\mathrm{V}}(f) \mathrm{e}^{\mathrm{i} 2 \pi \mathrm{f} \tau} \mathrm{df}=\int_{-\infty}^{+\infty} S^{\mathrm{V}}(\mathrm{f}) \cos (2 \pi f \tau) \mathrm{df}$

Knowing the value of the autocorrelation function, it is possible to find time $\tau_{1}$ for which the autocorrelation is equal to the calculated cross-correlation value considering null $\tau$. Thereby, the temporal functions at points 1 and 2, especially correlated, can be expressed by the same temporal series, with a time lag equal to $\tau_{1}$.

The following list is a brief description of the stages which need to be followed in order to obtain a spatial correlation between neighboring temporal series:

a) define bandwidth $\Delta \mathrm{L}$ for the temporal series;

b) define the cross-correlation value $\mathrm{C}_{1}$;

c) define the time interval $\tau_{1}$;

d) creation of the temporal series according to the subclause 3.3, separated by a $\tau_{1}$ time interval.

\section{NBR 6123 procedure for dynamic analysis}

\subsection{Overview}

The ABNT NBR 6123:1988 [2] standard presents two methodologies for the calculation of the structures subjected to dynamic effects due to atmospheric turbulence, namely:

- Simplified continuous model: recommended for a buildings with constant section and uniform distribution of mass;

- Discrete method: recommended for general cases of buildings, where there are variable properties with height.

In this work the discrete model is used for the analysis of a concrete 

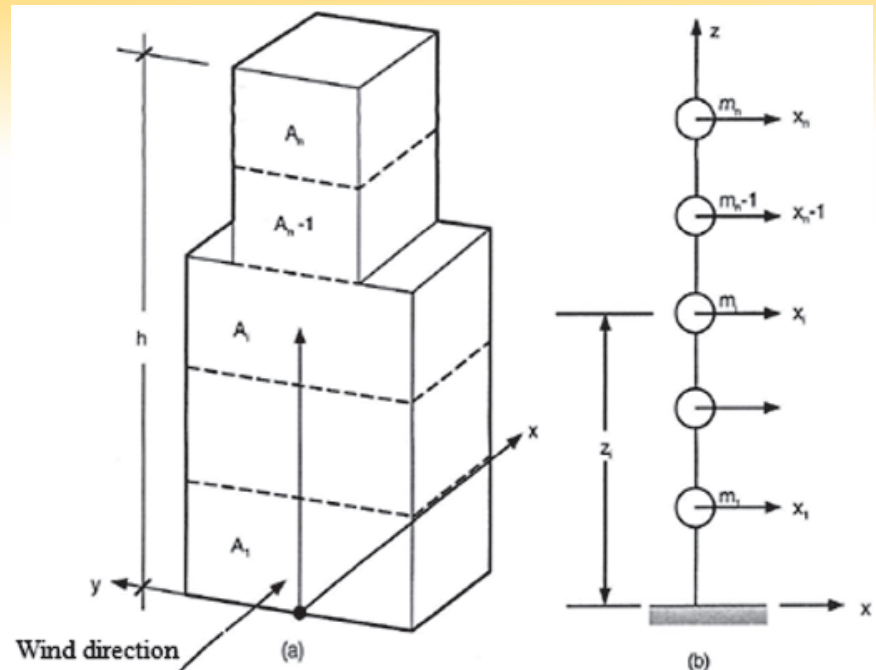

(b)

Figure 1

Scheme for the discrete dynamic model [1]

chimney (example present in annex I.2 of this standard), due to the fact that this structure presents variable properties with height.

\subsection{Basic formulation - discrete model}

The discrete model can be represented according to Figure 1, where:

$\mathrm{X}_{\mathrm{i}}$ is the displacement corresponding to the coordinate $\mathrm{i}$;

$A_{i}$ is the area of influence corresponding to the coordinate $i$;

$\mathrm{m}_{\mathrm{i}}$ is the discrete mass corresponding to the coordinate $\mathrm{i}$;

$z_{i}$ is the height of element i from ground level;

$n$ is the number of degrees of freedom $(i=1,2, \ldots, n)$;

Once the discretization of the structure is established, the natural frequencies $\mathrm{fj}$ and the modal form $\overrightarrow{\mathrm{x}}_{\mathrm{j}}$ corresponding to the mode $\mathrm{j}$, for $\mathrm{j}=1,2, \ldots, r$, where $r<n$, and $n$ is the number of modes retained in the solution. According to the requirements of Brazilian code ABNT NBR 6123:1988 [2], for buildings with a height of less than 150 meters, only the fist mode of vibration is considered sufficient, leading to a maximum error of $10 \%$. This recommendation is related to the fact that buildings with constant section and approximately uniform mass distribution present preponderant resonant response in the first mode of vibration. For slender structures or structures with heavily variable rigidities, the contributions of modes 1,2 , etc., must be computed successively until the equivalent forces regarding the last calculated mode are negligible.

For each mode of vibration $\mathrm{j}$, the total force due to the wind in the direction of the $\mathrm{x}$-axis is given by:

$F_{j}=\sum_{i=1}^{n} F_{i}=\sum_{i=1}^{n} \bar{F}_{i}+\hat{F}_{i}$

Table 1

Characteristics of the chimney according to ABNT NBR 6123:1988 [2]

\begin{tabular}{ccccc}
\hline $\mathbf{z}(\mathrm{m})$ & $\begin{array}{c}\text { External } \\
\text { diameter } \\
(\mathrm{m})\end{array}$ & $\begin{array}{c}\text { Wall } \\
\text { thickness } \\
(\mathrm{m})\end{array}$ & $\begin{array}{c}\text { Mass } \\
(\mathrm{kg} / \mathrm{m})\end{array}$ & $\begin{array}{c}\text { Moment of } \\
\text { inertia }\left(\mathrm{m}^{4}\right)\end{array}$ \\
\hline 180 & 4.75 & 0.17 & 9400 & 6.4 \\
130 & 5.9 & 0.17 & 10900 & 12.6 \\
80 & 7.42 & 0.25 & 17400 & 36.2 \\
35 & 8.82 & 0.6 & 38700 & 131.6 \\
0 & 9.86 & 0.6 & 43600 & 187.9 \\
\hline
\end{tabular}

where the average force $\bar{F}_{i}$ is equal to:

$\overline{\mathrm{F}}_{\mathrm{i}}=\overline{\mathrm{q}}_{\mathrm{o}} \mathrm{b}^{2} \mathrm{C}_{\mathrm{ai}} \mathrm{A}_{\mathrm{i}}\left(\mathrm{z}_{\mathrm{i}} / \mathrm{z}_{\mathrm{ref}}\right)^{2 \mathrm{p}}$

where:

$\mathrm{C}_{\mathrm{ai}}$ is the drag coefficient corresponding to the coordinate $\mathrm{i}$;

$z_{\text {ref }}$ is the reference height, equal to 10 meters;

$b$ and $p$ are coefficients dependent on the terrain type, indicated by ABNT NBR 6123:1988 [2];

$\mathrm{C}_{\mathrm{ai}}$ are the drag coefficients corresponding to the $\mathrm{x}$ coordinate.

The mean pressure is given by:

$\overline{\mathrm{q}}_{\mathrm{o}}=0,613\left(\overline{\mathrm{V}}_{\mathrm{p}}\right)^{2}\left(\overline{\mathrm{q}}_{\mathrm{o}}\right.$ in $\mathrm{N} / \mathrm{m}^{2}$ e $\overline{\mathrm{V}}_{\mathrm{p}}$ in $\left.\mathrm{m} / \mathrm{s}\right)$

where $\bar{V}_{p}$ is the project velocity.

The floating component $\hat{\mathrm{F}}_{\mathrm{i}}$ is defined as:

$\hat{\mathrm{F}}_{\mathrm{i}}=\mathrm{F}_{\mathrm{H}} \Psi_{\mathrm{i}} \mathrm{x}_{\mathrm{i}}$

where:

$\Psi_{\mathrm{i}}=\mathrm{m}_{\mathrm{i}} / \mathrm{m}_{\mathrm{o}}$

$\mathrm{F}_{\mathrm{H}}=\overline{\mathrm{q}}_{\mathrm{o}} \mathrm{b}^{2} \mathrm{~A}_{\mathrm{o}} \frac{\sum_{\mathrm{i}=1}^{\mathrm{N}} \beta_{\mathrm{i}} \mathrm{x}_{\mathrm{i}}}{\sum_{\mathrm{i}=1}^{\mathrm{N}} \psi_{\mathrm{i}} \mathrm{x}_{\mathrm{i}}{ }^{2}} \xi$

$\beta_{\mathrm{i}}=\mathrm{C}_{\mathrm{ai}}\left(\mathrm{A}_{\mathrm{i}} / \mathrm{A}_{\mathrm{o}}\right)\left(\mathrm{z}_{\mathrm{i}} / \mathrm{z}_{\mathrm{ref}}\right)^{\mathrm{p}}$

In the above equations, $m_{\circ}$ and $A_{\circ}$ are arbitrary reference values of mass and area, respectively; $\xi$ is the dynamic amplification coefficient, proposed for the five land categories; $\zeta$ is the critical damping ratio, proposed for several types of structures in ABNT NBR 6123:1988 [2].

\section{Concrete chimney structure description}

The structure of the chimney evaluated in this work is shown in the example of Annex I of the standard ABNT NBR 6123:1988 [2]. Tables 1 and 2 present the characteristics of the chimney and the properties of the adopted model.

The elasticity modulus considered for the concrete was $26.22 \mathrm{GPa}$ and poisson coefficient equal to 0.2 . The terrain was considered Type III and the critical damping ratio equal to $\zeta=0.01$ (reinforced concrete intrinsic damping). The factors $S_{1}$ and $S_{3}$ were taken equal to 1.0 and the velocity $V_{0}$ equal to $39.4 \mathrm{~m} / \mathrm{s}$.

The details of the discrete model procedure application according to ABNT NBR 6123:1988 [2] in chimney structure can be seen in Annex I of this standard. The numerical model developed and the application of the proposed procedure will be presented as follows.

\section{Table 2}

Properties and discretization of the structure according to ABNT NBR 6123:1988 [2]

\begin{tabular}{ccccc}
\hline $\mathbf{z}_{\mathrm{i}}(\mathrm{m})$ & $\mathbf{x}_{\mathrm{i}}$ & $\mathbf{m}_{\mathrm{i}}(\mathrm{kg})$ & $\mathbf{A}_{\mathbf{i}}\left(\mathbf{m}^{2}\right)$ & $\mathbf{C}_{\mathrm{ai}}$ \\
\hline 20 & 1 & 1254 & 282.5 & 0.6 \\
40 & 0.83 & 750 & 173.2 & 0.6 \\
60 & 0.68 & 463.8 & 141.4 & 0.6 \\
75 & 0.56 & 292.5 & 114 & 0.6 \\
90 & 0.46 & 232.5 & 107.2 & 0.6 \\
105 & 0.36 & 195 & 99.9 & 0.6 \\
120 & 0.28 & 174.4 & 93 & 0.6 \\
135 & 0.2 & 163.1 & 86.9 & 0.6 \\
150 & 0.14 & 153.7 & 81.6 & 0.6 \\
165 & 0.07 & 146.2 & 76.4 & 0.6 \\
180 & 0.03 & 70.9 & 36.3 & 0.6 \\
\hline
\end{tabular}




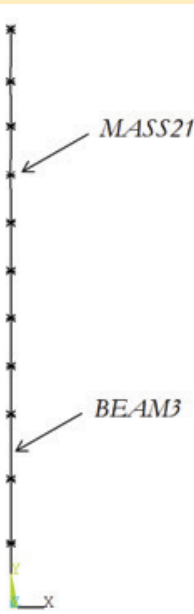

\section{Figure 2}

Numerical model developed at the Ansys ${ }^{\circledR}$

\section{Numerical model description and proposed procedure application}

For the application of the proposed procedure to the chimney structure, a finite element model was developed using beam elements (BEAM3). The masses were considered concentrated in numerical model nodes, through MASS21 elements. The geometric properties and the mass distribution are shown in Tables 1 and 2 . The boundary conditions were translations and rotation prevented and the wind forces were applied in axis $\mathrm{X}$ positive direction. Figure 2 shows the model developed with the coordinate system considered

The procedure initially considered the constant average velocity for all nodes of the numerical model, once they are at the same height. However, in the problem under analysis, the velocity varied considerably over the structure height. Thus, a weighted average of the product between the pressures and areas of each node was performed, in order to determine a mean velocity value to be used in the proposed procedure. The average velocity adopted in the analysis, from the weighted average, was equal to $33.45 \mathrm{~m} / \mathrm{s}$. The routine developed for constant height can be generalized to variable $z$, which will be the subject of further studies. The calculated time interval, used in the time series lag between the nodes, was equal to 1.77 seconds. The time increment ("timestep") used in the solution was equal to 0.1 seconds.

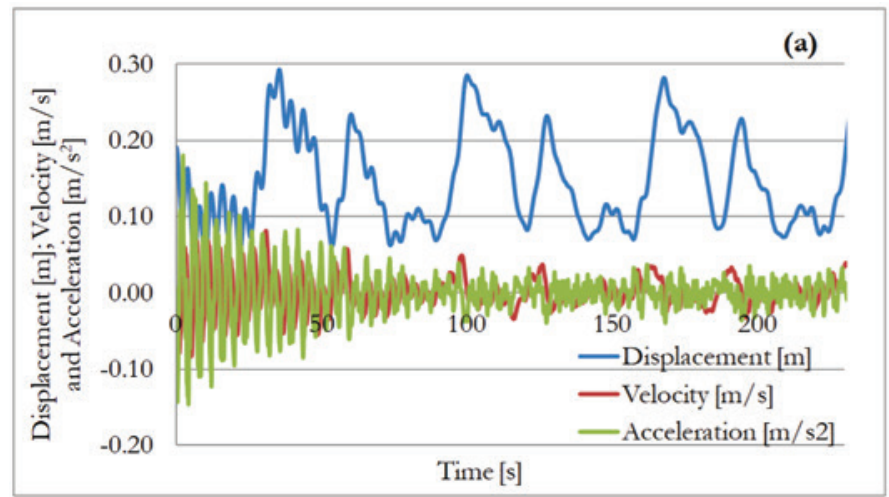

Table 3

Natural frequencies of the chimney structure

\begin{tabular}{ccc}
\hline Mode & $\begin{array}{c}\text { Natural frequency } \\
{[\mathrm{Hz}]}\end{array}$ & Description \\
\hline $1^{\circ}$ & 0.257 & First bending mode \\
$2^{\circ}$ & 0.909 & Second bending mode \\
$3^{\circ}$ & 2.163 & Third bending mode \\
$4^{\circ}$ & 3.834 & Fourth bending mode \\
$5^{\circ}$ & 6.319 & Fifth bending mode \\
$6^{\circ}$ & 10.567 & Sixth bending mode \\
$7^{\circ}$ & 16.188 & Seventh bending mode \\
\hline
\end{tabular}

The critical damping ratio of $\zeta=0.01$ resulted in multiplicative coefficients of mass and stiffness matrices, $\alpha$ and $\beta$, equal to 0.032 and 0.00021 , respectively.

\section{Results}

\subsection{Chimney modal analysis}

The natural frequencies of the chimney structure were determined through the numerical model, presented in Table 3.

The first natural frequency is close to the value determined by the approximate formulation present in ABNT NBR 6123: 1988 [2], where the first natural frequency is given by $f_{1}=1 /(0,02 \times h)=0,28$ $\mathrm{Hz}$, with the height of the chimney in meters.

\subsection{Comparison between results of dynamic analysis of the chimney structure and results of ABNT NBR 6123: 1988 [2]}

After the development of the dynamic analysis it was possible to obtain the time series of the displacements, velocities and accelerations of the chimney top node, and the support reactions of the base node of the structure, shown in Figures 3 and 4, respectively. Table 4 shows the maximums for each time series. The presented values were obtained with and without consideration of the geometric nonlinearity, and both cases without the consideration of aerodynamic damping.

The initial values were not taken into account since they were affected by the transient period of introduction of the forces corresponding to the mean component of the wind speed.

Comparing the time series and the maximum values it is possible to conclude that the geometric nonlinearity consideration in the

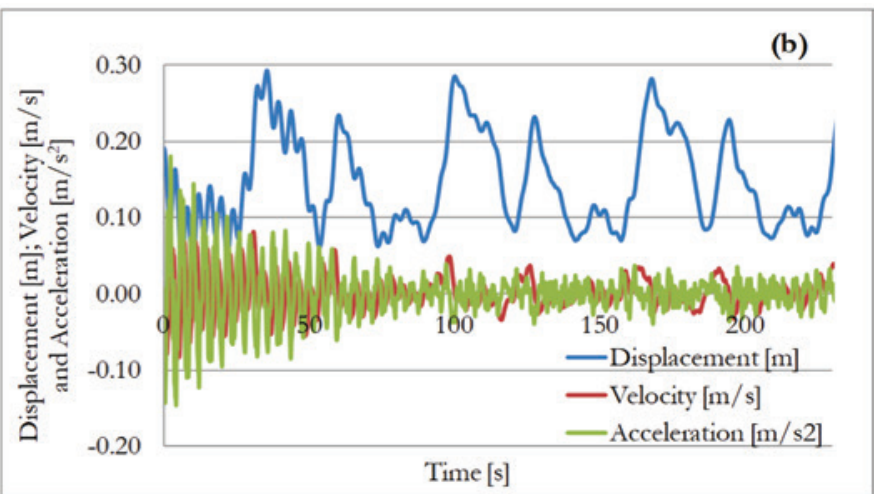

\section{Figure 3}

Time series of displacements, velocities and accelerations with (a) and without (b) the geometric non-linearity consideration 

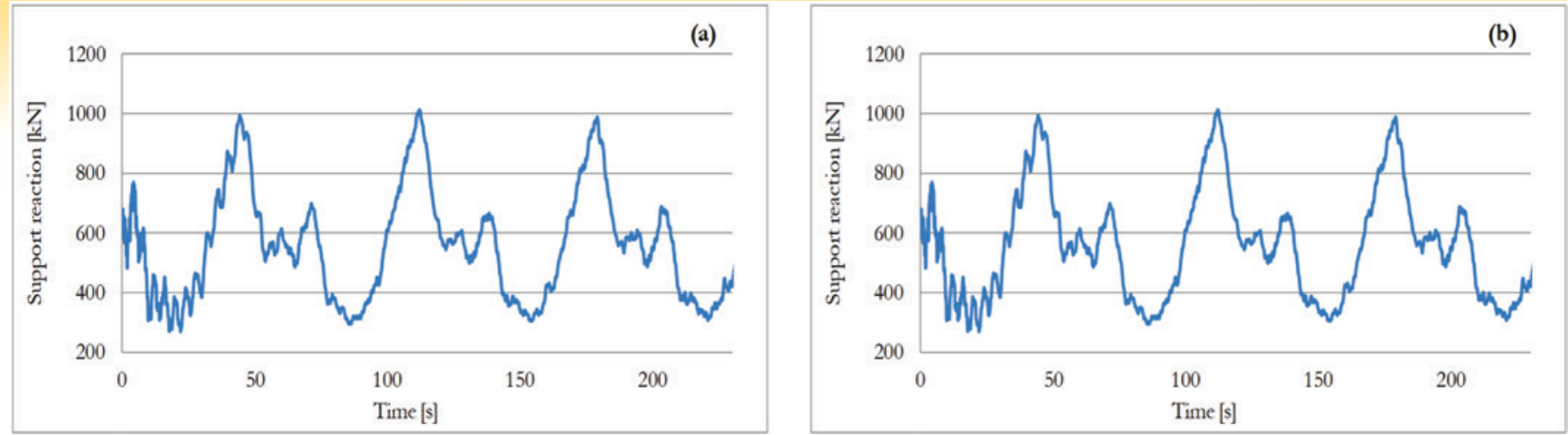

\section{Figure 4}

Time series of the support reaction in the direction of wind speed with (a) and without (b) the geometric non-linearity consideration

\section{Table 4}

Maximum values of displacement, velocity, acceleration and support reaction with and without the geometric non-linearity consideration

\begin{tabular}{cccc}
\cline { 2 - 4 } & $\begin{array}{c}\text { With } \\
\text { geometric } \\
\text { non-linearity }\end{array}$ & $\begin{array}{c}\text { Without } \\
\text { geometric } \\
\text { non-linearity }\end{array}$ & $\begin{array}{c}\text { Difference } \\
{[\%]}\end{array}$ \\
\hline $\begin{array}{c}\text { Displacement } \\
{[\mathrm{m}]}\end{array}$ & 0.2936 & 0.2918 & 0.60 \\
$\begin{array}{c}\text { Velocity }[\mathrm{m} / \mathrm{s}] \\
\text { Acceleration } \\
{\left[\mathrm{m} / \mathrm{s}^{2}\right]}\end{array}$ & 0.0840 & 0.0809 & 3.70 \\
$\begin{array}{c}\text { Support } \\
\text { reaction } \mathrm{F}_{\mathrm{x}}\end{array}$ & 0.1784 & 0.1763 & 1.17 \\
{$[\mathrm{kN}]$} & 1011.7 & 1008.5 & 0.31 \\
$\begin{array}{c}\text { Bending in } \\
\text { support M } \\
{[\mathrm{kN} . \mathrm{m}]}\end{array}$ & 79315.0 & 78092.8 & 1.54 \\
\hline
\end{tabular}

dynamic analysis of the chimney under study did not significantly influence in the results, being the maximum difference less than $4 \%$. This is mainly due to the small displaceability of the structure.

Figure 5 shows the time series of displacements, velocities and accelerations of the chimney top node and the support reactions, taking into account aerodynamic damping and the effect of geometric nonlinearity. Table 5 shows the maximums for each time series.

The maximum values calculated for the displacements, veloci-

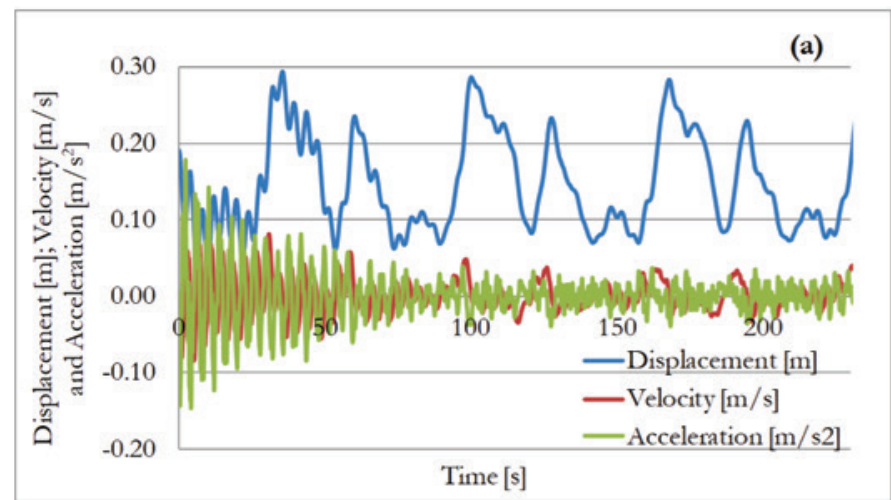

ties, accelerations and support reactions obtained with aerodynamic damping were lower by up to $2.24 \%$ than the values obtained without considering damping. It is observed that the maximum speed value of the top of the chimney $(0.08 \mathrm{~m} / \mathrm{s})$ wan considerably lower than the values adopted for wind speed. Although the consideration of aerodynamic damping reduces the maximum values obtained, it is not relevant in the behavior of the structure under analysis.

\section{Table 5}

Maximum values of displacement, velocity, acceleration and support reaction with and without aerodynamic damping consideration (with geometric non-linearity)

\begin{tabular}{cccc}
\cline { 2 - 4 } & $\begin{array}{c}\text { With } \\
\text { aerodynamic } \\
\text { damping }\end{array}$ & $\begin{array}{c}\text { Without } \\
\text { aerodynamic } \\
\text { damping }\end{array}$ & $\begin{array}{c}\text { Difference } \\
{[\%]}\end{array}$ \\
\hline $\begin{array}{c}\text { Displacement } \\
{[\mathrm{m}]}\end{array}$ & 0.2899 & 0.2936 & 1.28 \\
$\begin{array}{c}\text { Velocity }[\mathrm{m} / \mathrm{s}] \\
\begin{array}{c}\text { Acceleration } \\
{\left[\mathrm{m} / \mathrm{s}^{2}\right]}\end{array}\end{array}$ & 0.0822 & 0.0840 & 2.24 \\
$\begin{array}{c}\text { Support } \\
\text { reaction } \mathrm{F}_{\mathrm{x}} \\
{[\mathrm{kN}]}\end{array}$ & 0.1767 & 0.1784 & 0.95 \\
$\begin{array}{c}\text { Bending in } \\
\text { support } \mathrm{M}_{z} \\
{[\mathrm{kN} . \mathrm{m}]}\end{array}$ & 7008.9 & 1011.7 & 0.27 \\
\hline
\end{tabular}

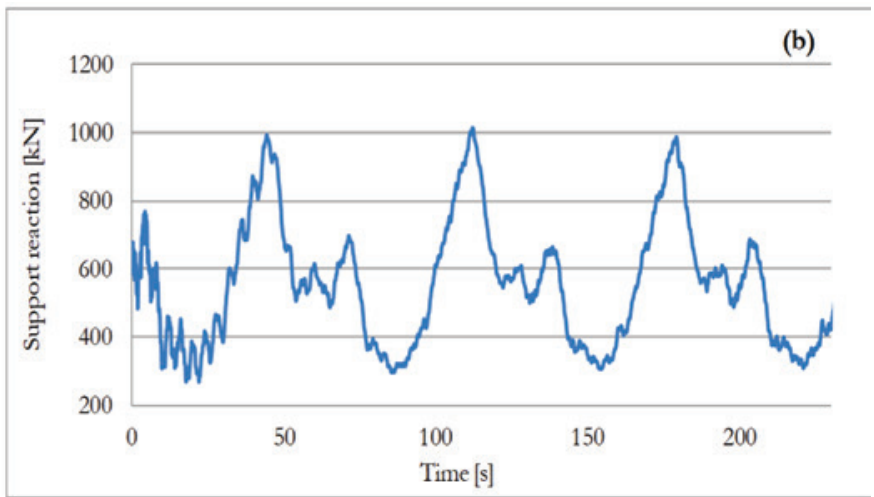

\section{Figure 5}

Time series of displacements, velocities, accelerations (a) and support reactions (b) taking into consideration of aerodynamic damping and geometric non-linearity 
Table 6

Comparison of the maximum reactions according to the methodologies evaluated

\begin{tabular}{ccc}
\hline $\begin{array}{c}\text { ABNT NBR } \\
\text { 6123:1988 [kN] }\end{array}$ & $\begin{array}{c}\text { Proposed } \\
\text { procedure [kN] }\end{array}$ & Difference [\%] \\
\hline 180 & 4.75 & 0.17 \\
\hline
\end{tabular}

Table 6 shows the maximum values of the support reactions $\left(F_{x}\right)$ obtained through the procedure in ABNT NBR 6123:1988 [2] and the proposed methodology, taking into account the effect of geometric non-linearity and aerodynamic damping.

Considering the difference observed in the comparison of the responses, the result obtained with the proposed procedure is considered acceptable, once the result obtained through the procedure of standard ABNT NBR 6123:1988 [2] is simplified and was determined with the consideration of only the first mode of the structure. The difference presents the same order of the expected error value for this simplification, indicated in ABNT NBR 6123:1988 [2] and confirmed by Blessmann [1], equal to $10 \%$.

It is important to note that the differences found (12.5\%) are not due to the consideration of geometric non-linearity or aerodynamic damping, since the structure presented similar answers without these considerations.

In order to better verify the influence of geometric nonlinearity and aerodynamic damping on high chimney structures, the evaluation of a hypothetical chimney with lower rigidity is proposed, whose results are found as follows.

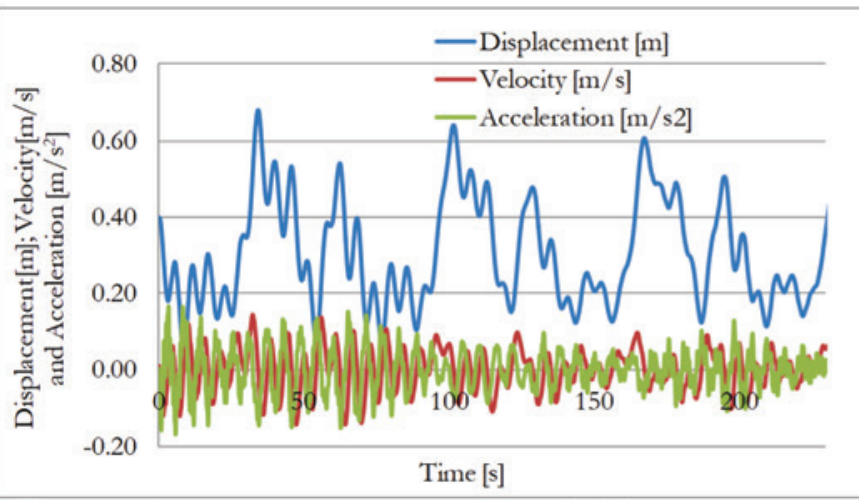

\subsection{Dynamic analysis of the chimney structure with reduced inertia}

In order to evaluate the relationship between the results obtained previously and the rigidity of the structure, the dynamic behavior of a hypothetical chimney with the same properties of the chimney evaluated before, but with the inertia reduced by half, was analyzed. The other parameters and the wind load were kept unchanged. Table 7 presents the first natural frequencies obtained for the structure of the chimney with reduced inertia.

The time series of the displacements, velocities and accelerations of the chimney top node and the support reactions are shown in Figures 6 and 7, respectively. Table 8 shows the maximums for

\section{Table 7}

Natural frequencies of the chimney structure with reduced inertia

\begin{tabular}{ccc}
\hline Mode & $\begin{array}{c}\text { Natural frequency } \\
{[\mathrm{Hz}]}\end{array}$ & Description \\
\hline $1^{\circ}$ & 0.182 & First bending mode \\
$2^{\circ}$ & 0.643 & Second bending mode \\
$3^{\circ}$ & 1.529 & Third bending mode \\
$4^{\circ}$ & 2.711 & Fourth bending mode \\
$5^{\circ}$ & 4.468 & Fifth bending mode \\
$6^{\circ}$ & 7.472 & Sixth bending mode \\
$7^{\circ}$ & 11.447 & Seventh bending mode \\
\hline
\end{tabular}

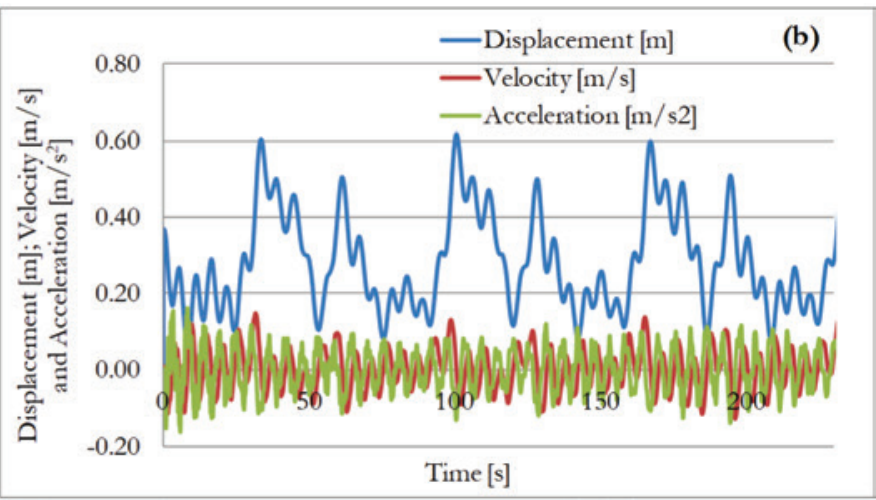

\section{Figure 6}

Time series of displacements, velocities and accelerations with (a) and without (b) the geometric non-linearity consideration for the chimney with reduced inertia
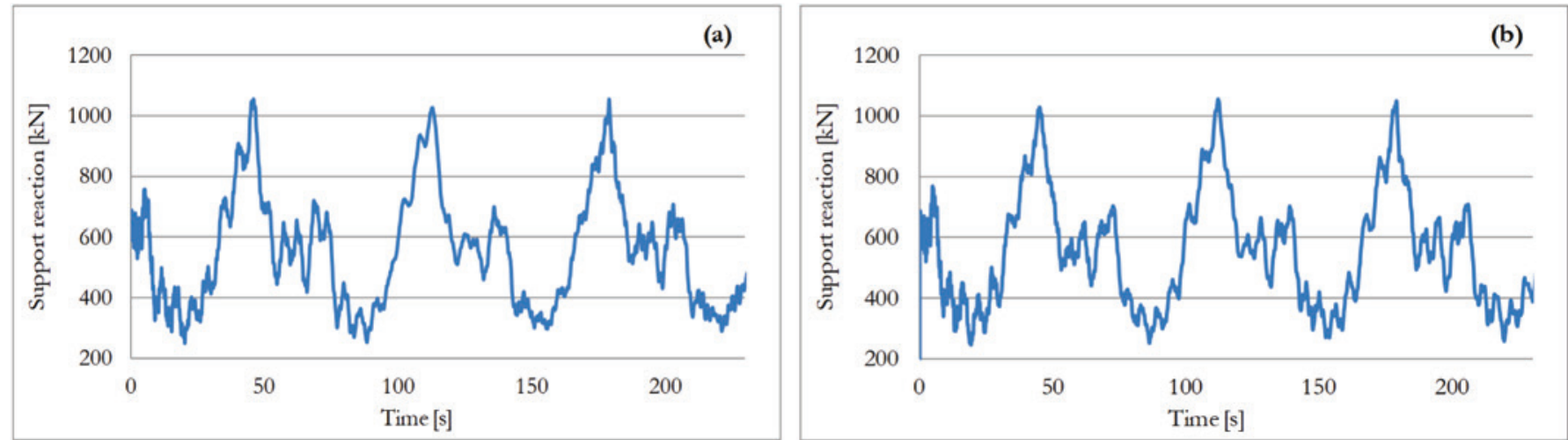

\section{Figure 7}

Time series of the support reaction in the direction of wind speed with (a) and without (b) the geometric non-linearity consideration for the chimney with reduced inertia 


\section{Table 8}

Maximum values of displacement, velocity, acceleration and support reaction with and without the geometric non-linearity consideration for the chimney with reduced inertia

\begin{tabular}{cccc}
\cline { 2 - 4 } & $\begin{array}{c}\text { With } \\
\text { geometric } \\
\text { non-linearity }\end{array}$ & $\begin{array}{c}\text { Without } \\
\text { geometric } \\
\text { non-linearity }\end{array}$ & $\begin{array}{c}\text { Difference } \\
{[\%]}\end{array}$ \\
\hline $\begin{array}{c}\text { Displacement } \\
{[\mathrm{m}]}\end{array}$ & 0.6784 & 0.6179 & 8.92 \\
$\begin{array}{c}\text { Velocity [m/s] } \\
\text { Acceleration } \\
{\left[\mathrm{m} / \mathrm{s}^{2}\right]}\end{array}$ & 0.1419 & 0.1464 & 3.21 \\
$\begin{array}{c}\text { Support } \\
\text { reaction } \mathrm{F}_{\mathrm{x}} \\
{[\mathrm{kN}]}\end{array}$ & 0.1646 & 0.1629 & 1.04 \\
$\begin{array}{c}\text { Bending in } \\
\text { support M } \\
{[\mathrm{kN} . \mathrm{m}]}\end{array}$ & 1057.1 & 1055.8 & 0.11 \\
\hline
\end{tabular}

each time series. The presented values were obtained with and without consideration of the geometric nonlinearity, and both cases without the consideration of aerodynamic damping.

The geometric non-linearity consideration in the analysis of the chimney with reduced inertia resulted in the increase of the displacements and maximum support reactions of $9 \%$ and $6 \%$, respectively.

Figure 8 shows the time series of displacements, velocities and accelerations of the chimney top node and the support reactions, with consideration of aerodynamic damping and the effect of geometric nonlinearity. Table 9 shows the maximums for each time series.

Again, the maximum values obtained with aerodynamic damping were lower than those obtained without damping. However, even with the increased velocities assumed by the modified structure, the effect of aerodynamic damping is negligible and the behavior of the structure is not significantly changed $(1.25 \%$ reduction of maximum bending in the support).

The reduction of the rigidity of the structure implied, in relation to the results obtained for the original structure, in the increase of $130 \%$ of the maximum displacement and $61 \%$ of the maximum speed. For the support reactions, the increase was $4.40 \%$ of the horizontal reaction $\left(F_{x}\right)$ and $6.50 \%$ for the bending at the base $\left(M_{z}\right)$. The increases were due to the consideration of the geometric nonlinearity of the structure, and aerodynamic damping did not have a considerable influence on the results.

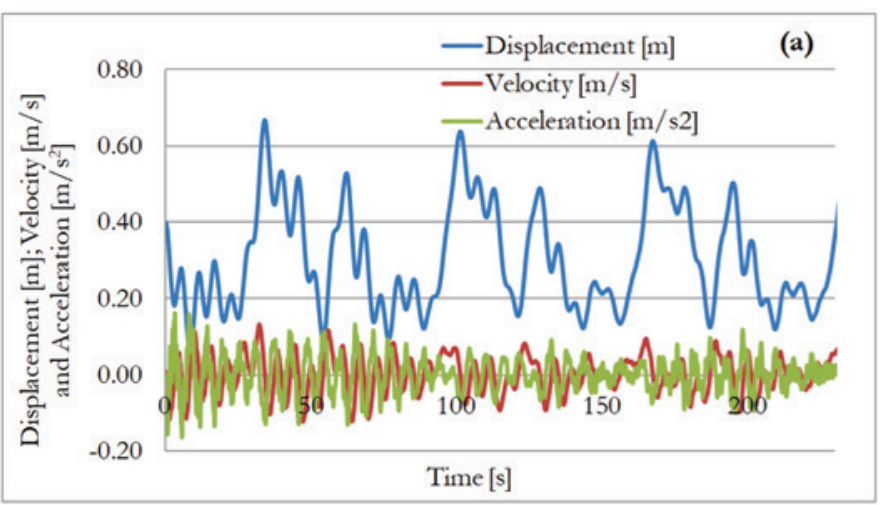

\section{Conclusions}

A numerical procedure for the analysis of the dynamic behavior of concrete chimneys subjected to wind forces was proposed in this work. Geometric non-linearity and aerodynamic damping had their quantified influences on the dynamic response of the structure. Finally, the obtained results were compared with those determined from the simplified procedure for the dynamic analysis of structures present in ABNT NBR 6123:1988 [2].

For the evaluation of the proposed methodology, a 180-meter-high concrete chimney was considered, according to the example of ABNT NBR 6123:1988 [2]. For this structure, the geometric nonlinearity and aerodynamic damping considerations did not result in significant changes in the dynamic response, due to the low displacement and the small velocity values assumed by the structure. The efforts, when compared to those obtained through the procedure in ABNT NBR 6123:1988 [2], were 12.5\% higher. In view of the difference observed, the result obtained with the proposed procedure was considered acceptable, once that the procedure of ABNT NBR 6123:1988 [2] is simplified and was determined using only the first mode of the structure. The difference presents the same order of the expected error value for this simplification, indicated in ABNT NBR 6123:1988 [2] and confirmed by Blessmann [1], equal to $10 \%$.

\section{Table 9}

Maximum values of displacement, velocity, acceleration and support reaction with and without aerodynamic damping consideration for the chimney with reduced inertia (with geometric non-linearity)

\begin{tabular}{cccc}
\cline { 2 - 4 } & $\begin{array}{c}\text { With } \\
\text { aerodynamic } \\
\text { damping }\end{array}$ & $\begin{array}{c}\text { Without } \\
\text { aerodynamic } \\
\text { damping }\end{array}$ & $\begin{array}{c}\text { Difference } \\
{[\%]}\end{array}$ \\
\hline $\begin{array}{c}\text { Displacement } \\
{[\mathrm{m}]}\end{array}$ & 0.6679 & 0.6784 & 1.57 \\
$\begin{array}{c}\text { Velocity }[\mathrm{m} / \mathrm{s}] \\
\text { Acceleration } \\
{\left[\mathrm{m} / \mathrm{s}^{2}\right]}\end{array}$ & 0.1324 & 0.1419 & 7.17 \\
$\begin{array}{c}\text { Support } \\
\text { reaction } \mathrm{F}_{\mathrm{x}} \\
{[\mathrm{kNN}]}\end{array}$ & 0.1649 & 0.1646 & 0.19 \\
$\begin{array}{c}\text { Bending in } \\
\text { support } \mathrm{M}_{z} \\
{[\mathrm{kN} . \mathrm{m}]}\end{array}$ & 83458.5 & 84506.8 & \\
\hline
\end{tabular}

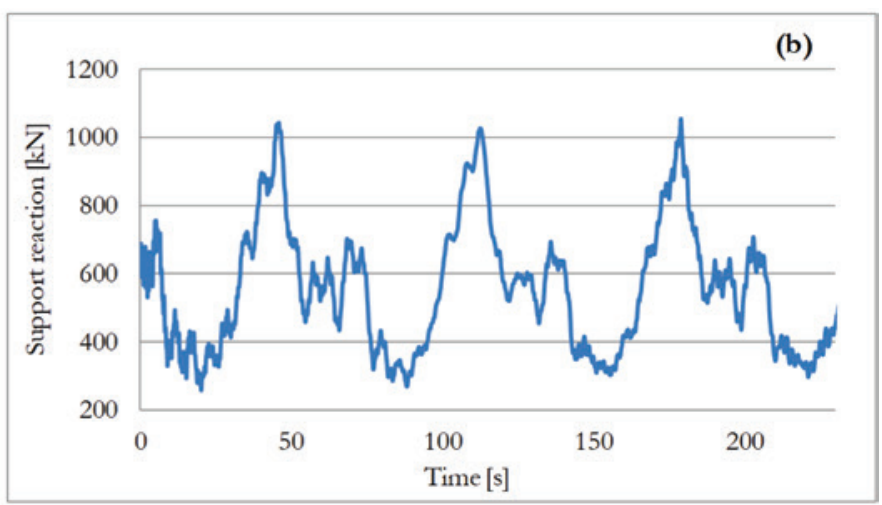

\section{Figure 8}

(a) Time series of displacements, velocities, accelerations (a) and support reactions (b) taking into consideration of aerodynamic damping and geometric non-linearity for the chimney with reduced inertia 
Even for the higher values of velocity observed in the structure with reduced inertia, aerodynamic damping did not cause measurable changes to the structure response. The latter confirms that aerodynamic damping is irrelevant for low structural speeds.

\section{References}

[1] Blessmann, J. Introdução as estudo das ações dinâmicas do vento, 2. ed. Porto Alegre: Ed. Universidade/ UFRGS, 2005.

[2] ASSOCIAÇÃO BRASILEIRA DE NORMAS TÉCNICAS ABNT. NBR 6123: Forças devidas ao Vento em Edificações. Rio de Janeiro, 1988.

[3] Hirsh, G.; Bachman, H. Wind induced vibrations. Vibration Problems in Structures. Zurich: Institut fur Baustatik und Konstruktion/Birkhauser Verlag Basel, 1995.

[4] Caracoglia, L. A stochastic model for examining alongwind loading uncertainty and intervention costs due to windinduced damage on tall buildings. Engineering Structures, v. 78, p. 121-132, 2014.

[5] Bobby, S.; Spence, S.M.J.; Bernardini; E. Kareem. A. Performance-based topology optimization for wind-excited tall buildings: A framework. Engineering Structures, v. 74, p. 242-255, 2014.

[6] Ambrosini, R.D.; Riera, J.D. Analysis of structures subjected to random wind loading by simulation in the frequency domain. Probabilistic Engineering Mechanics, p. 233-239, 2002.

[7] Belloli, M.; Rosa, L.; Zasso, A. Wind loads and vortex shedding analysis on the effects of the porosity on a high slender tower. Journal of Wind Engineering and Industrial Aerodynamics, v. 126, p. 75-86, 2014.

[8] John, A.D.; Gairola, A., Ganju, E.; Gupta, A. Design wind loads on reinforced concrete chimney - An experimental case study. Procedia Engineering, v. 14, p 1252-1257, 2011.

[9] Tamura, Y.; Kohsaka, R.; Nakamura, O., Miyashita, K. Modi, $V$. Wind-induced responses of an airport tower-efficiency of tuned liquid damper. Journal Wind Engineering \& Industrial Aerodynamics, 65:121-31, 1996.

[10] Henriques, J.; Paiva, F.; Barros, R. Wind action in the tower testing station. International Conference on Wind Engineering, Porto Alegre, 2015

[11] Koss, H.H.H.; Srouji, R.G. Scaling issues in the determination of wind loads on lattice masts. International Conference on Wind Engineering, Porto Alegre, 2015.

[12] Ke, S.T; Ge, Y.J. The influence of self-excited forces on wind loads and wind effects for super-large cooling towers. Journal of Wind Engineering and Industrial Aerodynamics, v. 132, p. 125-135, 2014

[13] Yang, F.; Yang, J.; Niu, H., Zhang, H. Design wind loads for tubular-angle steel cross-arms of transmission towers under skewed wind loading. Journal of Wind Engineering and Industrial Aerodynamics, v. 140, p. 10-18, 2015.

[14] Franco, M. Direct along-wind dynamic analysis of tall structures. Boletim técnico da Escola Politécnica da Universidade de São Paulo BT/PEF/9303, São Paulo, 1993.
[15] Davenport, A.G. The prediction of the response of structures to gust wind. International Research Seminar on Safety of Structures under Dynamic Loading, Trondhei, v. 1, p. 257-284, 1978.

[16] Davenport A.G. The response of tensions structures to turbulent Wind: the role of aerodynamic damping. 1st International Oleg Kerensky Memorial Conference on Tension Structures. London, 1988.

[17] Carvalho, H. Efeitos do vento em linhas de transmissão. 2015. Tese (Doutorado) - Departamento de Engenharia de Estruturas, Universidade Federal de Minas Gerais, Belo Horizonte.

[18] ANSYS-12.1. Release 1.0 Documentation for Ansys. Canonsburg, United States, 2009.

[19] Blessmann, J. O vento na engenharia estrutural, 1. ed. Porto Alegre: Ed. Universidade/ UFRGS, 1995.

[20] Nagao, F. et al. Basic study on spatial correlations of fluctuating lifts acting on plates. Journal of Wing Engineering, v. 91, p. 1349-1361, 2003.

[21] Pfeil, M.S. Battista, R.C. Aerodynamic stability analysis of cable-stayed bridges. Journal of Structural Engineering, v. 121, p. 1784-1788, 1995.

[22] Davenport, A.G. Buffeting of a suspension bridge by stormy winds. Journal of the Structural Division, ASCE, v. 88, n. ST3, 1962.

[23] Simiu, E.; Scanlan, R.H. Wind Effects on Structures: Na Introduction to Wind Engineering, 2. ed. New York: John Wiley and Sons, 1986. 